\title{
THE GLOMERULAR CLEARANCE AND RENAL TRANSPORT OF HEMOGLOBIN IN ADULT MALES
}

\author{
By JEROME LOWENSTEIN,* DYREL A. FAULSTICK, MARVIN J. YIENGST AND \\ NATHAN W. SHOCK \\ (From the Gerontology Branch, National Heart Institute, Bethesda, and the Baltimore City \\ Hospitals, Baltimore, $M d$.)
}

(Submitted for publication January 16, 1961 ; accepted March 16, 1961)

The demonstration by Polonovski, Jayle, Boussier and Badin $(1,2)$ that certain plasma proteins have the property of binding extracorpuscular hemoglobin has led to recent re-evaluation of the mechanisms of renal transport of hemoglobin in the dog (3) and in man (4). Lathem (4) showed that circulating extracorpuscular hemoglobin is bound quantitatively to the $\alpha_{2}$-globulin, haptoglobin. By utilizing the infusion of autogenous hemoglobin solution, Lathem demonstrated that in man: 1) no unbound hemoglobin is found in the circulation until the plasma hemoglobin-binding capacity is saturated;2) hemoglobinuria does not occur unless unbound hemoglobin is present in the circulation; and 3) neither protein-bound hemoglobin nor methemalbumin appears in the urine during hemoglobinuria.

From the relationship between changing concentration of unbound hemoglobin in the plasma $\left(\Delta \mathrm{P}_{\text {free } \mathbf{H b}}\right)$ and urinary excretion rate $\left(\Delta \mathrm{U}_{\text {free } \mathbf{H b}} \mathrm{V}\right)$ an estimate of the glomerular clearance of hemoglobin $\left(\mathrm{C}_{\text {free } \mathbf{H b}}\right)$ may be obtained. As defined by Lathem (4), glomerular clearance of free hemoglobin $=\Delta \mathrm{U}_{\text {free } \mathbf{H b}} \mathrm{V} / \Delta \mathrm{P}_{\text {free } \mathbf{H b}}$.

Previous studies from this laboratory $(5,6)$ have demonstrated a sytematic decrease in glomerular filtration rate, effective renal plasma flow and various tubular transport maxima with age. A progressive loss of whole nephrons with aging has been proposed (5). Little is known of the effect of aging on the permeability characteristics of the glomerular membrane. Everitt (7) has reported a tenfold increase in the daily excretion of urinary protein nitrogen from youth to senility in the rat. Studies in mice by Thung (8) have demonstrated both qualitative and quantitative changes in proteinuria in older animals, but the relationship of these changes to glomerular perme-

* Present address: Department of Medicine, Bellevue Hospital, New York, N. Y. ability is not clearly established. This study was undertaken in order to determine whether there is any systematic age difference in glomerular permeability to hemoglobin in healthy adults free of clinical renal disease.

\section{METHODS}

Subjects. All subjects $(n=47)$ were ambulatory males chosen from the wards of the Baltimore City Hospitals or the Infirmary (Old People's Home). All subjects conformed to the following criteria: 1) lack of any history of renal disease; 2) normal blood urea nitrogen or nonprotein nitrogen; 3) absence of proteinuria (heat and acetic acid or sulfosalicylic acid tests); and 4) auscultatory diastolic blood pressure not above 90 $\mathrm{mm} \mathrm{Hg}$. All patients were afebrile at the time of testing. Patients from the tuberculosis wards had received no streptomycin, kanamycin or adrenocortical steroids for at least 5 years. The control values for inulin clearance $\left(C_{I n}\right)$ and para-aminohippurate clearance $\left(\mathrm{C}_{\mathrm{PAB}}\right)$ (corrected to $1.73 \mathrm{~m}^{2}$ surface area; Table I) agreed closely with those previously reported by Davies and Shock (6).

Experimental procedure. Patients were pretreated with $2 \mathrm{~g}$ of sodium bicarbonate by mouth every 4 hours, beginning at noon of the day prior to testing. All patients were in the fasting state and remained supine with the head of the bed at $0^{\circ}$ to $15^{\circ}$ throughout the study. Subjects were given 600 to $800 \mathrm{ml}$ of water orally 1 to 2 hours before study and $200 \mathrm{ml}$ each half hour during the test. Clearance studies were carried out according to the constant infusion technique of Smith, Goldring and Chasis (9), with an indwelling multieyed urethral catheter.

For each subject the plasma hemoglobin-binding. capacity was determined, prior to testing, by a modification of the method described by Lathem and Worley (10). After one 15-minute period for the determination of control inulin and $\mathrm{PAH}$ clearance, a priming dose of autogenous hemoglobin solution prepared as described below was infused. The quantity of hemoglobin was calculated in each case on the basis of the plasma hemoglobin-binding capacity, and was administered at a rate that would achieve saturation of the total circulating haptoglobin in 20 to 30 minutes. The priming dose was followed by a constant infusion of hemoglobin 
TABLE I

Renal function of normal males from Davies-Shock series compared with present studies

\begin{tabular}{|c|c|c|}
\hline & $\begin{array}{l}\text { Data of } \\
\text { Davies and } \\
\text { Shock (6) }\end{array}$ & $\begin{array}{l}\text { Present } \\
\text { study }\end{array}$ \\
\hline Number of subjects & 70 & 47 \\
\hline \multicolumn{3}{|l|}{$\begin{array}{l}\text { Glomerular filtration rate } \\
\left(\mathrm{ml} / \mathrm{min} / 1.73 \mathrm{~m}^{2} \text { surface area }\right)\end{array}$} \\
\hline $\mathrm{R}=$ correlation with age $\mathrm{e}^{*}$ & -0.68 & -0.71 \\
\hline $\begin{array}{l}\text { Slope of regression on age } \\
(\mathrm{ml} / \mathrm{yr})\end{array}$ & -0.96 & -1.00 \\
\hline $\begin{array}{l}\text { Value at age } 55 \text { calcu- } \\
\text { lated from regression } \\
(\mathrm{ml} / \mathrm{min})\end{array}$ & 100.4 & 97.9 \\
\hline \multicolumn{3}{|l|}{$\begin{array}{l}\text { Effective renal plasma flow } \\
\left(\mathrm{ml} / \mathrm{min} / 1.73 \mathrm{~m}^{2} \text { surface area }\right)\end{array}$} \\
\hline $\mathrm{R}=$ correlation with age & -0.65 & -0.76 \\
\hline $\begin{array}{l}\text { Slope of regression on age } \\
(\mathrm{ml} / \mathrm{yr})\end{array}$ & -6.44 & -6.90 \\
\hline $\begin{array}{l}\text { Value at age } 55 \text { calcu- } \\
\text { lated from regression } \\
(\mathrm{ml} / \mathrm{min})\end{array}$ & 486.0 & 450.5 \\
\hline
\end{tabular}

* Statistical methods (29).

at a rate of 40 to $80 \mathrm{mg}$ per minute to insure a gradual rise in plasma hemoglobin concentration which attained a mean maximal value of $178 \pm 67 \mathrm{mg}$ per $100 \mathrm{ml}$ (SD). Eight to twelve 15-minute urine collections were carried out, and blood samples were taken at the midpoint of each collection period via an indwelling needle in the femoral artery or vein. Auscultatory blood pressure and radial pulse were recorded near the midpoint of each urine collection period.

Preparation of hemoglobin solution. Fifty to $75 \mathrm{ml}$ of the patient's blood was introduced into each of two sterile $250 \mathrm{ml}$ Pyrex centrifuge bottles to which $75 \mathrm{ml}$ of sterile acid citrate dextrose solution had been previously added. After centrifugation at $2,000 \mathrm{rpm}$ for 1 hour, the supernatant was removed and $150 \mathrm{ml}$ of distilled water was added to lyse the red cells. After freezing and thawing to increase hemolysis, hypertonic saline was added to achieve isotonicity. This mixture was centrifuged for 2 hours at $0^{\circ} \mathrm{C}$ and 2,000 rpm. The supernatant hemoglobin solution was separated and stored at $4^{\circ} \mathrm{C}$ for a maximum of 24 hours before use.

Analytic methods. Inulin in protein-free filtrates of urine and plasma was determined by the method of Harrison (11) and para-aminohippurate by the method of Bratton and Marshall (12). Total serum hemoglobin was measured by a modification of the method of McCall (13) and urine hemoglobin concentration determined by the method of Crosby and Furth (14) after overnight dialysis of urine against isotonic saline.

Free and haptoglobin-bound hemoglobin in serum samples were separated by filter paper electrophoresis in a Durrum-type cell with a phosphate buffer ( $\mathrm{pH}$ 7.0, ionic strength 0.10 ) for a period of 16 hours. The paper strips were oven-dried at $115^{\circ} \mathrm{C}$ for 15 minutes and stained by thorough spraying with a $1: 1$ mixture of 1 per cent $\mathrm{H}_{2} \mathrm{O}_{2}$ and 1 per cent benzidine base in 90 per cent acetic acid. The relative proportions of free and protein-bound hemoglobin were evaluated in quadruplicate by photometric scanning (Spinco Analytrol) with a B-5 cam. Methemalbumin was never more than 1 per cent of the total hemoglobin and was not considered in the calculations.

Treatment of data. For each study, the plasma unbound hemoglobin concentration and the urinary hemoglobin excretion per milliliter of glomerular filtrate (to eliminate fluctuations due to emptying errors and timing) were plotted graphically and a straight line drawn by visual fit. The glomerular clearance of unbound hemoglobin relative to inulin $\left(\mathrm{C}^{\mathrm{G}}{ }_{\text {r ree } \mathrm{HB}} / \mathrm{C}_{\mathrm{In}}\right)$ was calculated from the slope of this line:

$$
\frac{\mathrm{C}_{\text {free } \mathrm{Hb}}}{\mathrm{C}_{\mathrm{In}_{\mathrm{n}}}}=\frac{\Delta \mathrm{U}_{\text {free } \mathrm{Hb}} \mathrm{V} / \mathrm{C}_{\mathrm{In}}}{\Delta \mathrm{P}_{\text {free } \mathrm{Hb}}}
$$

The rate of tubular reabsorption of hemoglobin ( $\left.T_{\text {r ree Hв }}\right)$ was calculated as the difference between the filtered load and the urinary excretion rate for each collection period and the mean value calculated:

$$
\underset{(\mathrm{mg} / \mathrm{min})}{\text { filtered load }}=\frac{\mathrm{C}_{\text {free } \mathrm{Hb}}}{\mathrm{C}_{\mathrm{In}}} \times \mathrm{C}_{\mathrm{In}_{\mathrm{n}}} \times \mathrm{P}_{\text {free } \mathrm{Hb}}
$$

$\underset{(\mathrm{mg} / \mathrm{min})}{\mathrm{T}_{\mathrm{Hb}}}=\left[\frac{\mathrm{C}_{\text {free Hb}}}{\mathrm{C}_{I_{n}}} \times \mathrm{C}_{\text {In }} \times \mathrm{P}_{\text {free Hb}}\right]-\mathrm{U}_{\text {free Hb}} \mathrm{V}[3]$

\section{RESULTS}

Glomerular clearance of hemoglobin relative to inulin. In 51 of the 59 studies carried out, the graphic relationship between urinary excretion and plasma levels of free hemoglobin was linear (Fig-

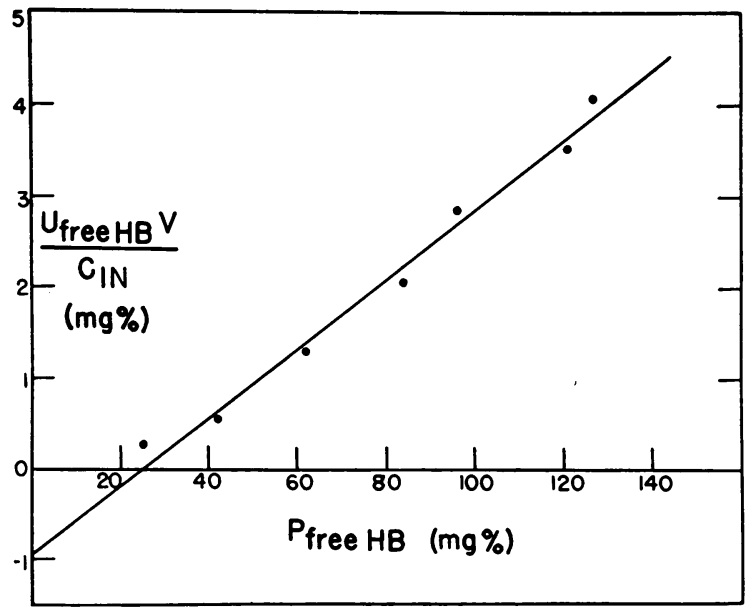

Fig. 1. The RELATIONSHIP BETWEeN THE EXCRETORY RATE AND THE CONCENTRATION OF FREE HEMOGLOBIN IN PLASMA (REPRESENTATIVE EXPERIMENT). 

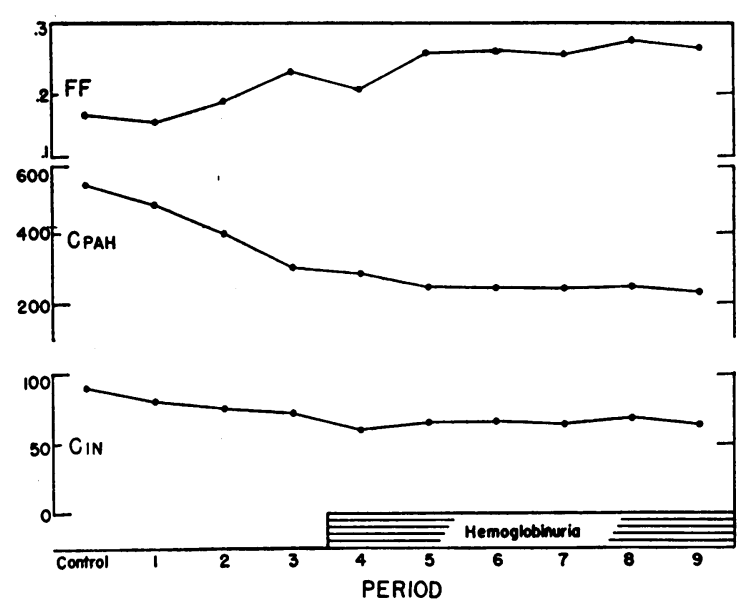

Fig. 2. Hemodynamic Changes during infusion of HeMoglobin solution. Clearances of inulin $\left(\mathrm{C}_{\text {In }}\right)$ and para-aminohippurate $\left(\mathrm{C}_{\mathrm{PAH}}\right)$ are expressed in $\mathrm{ml} / \mathrm{min}$. It can be seen that the maximal hemodynamic changes occur during the priming infusion of hemoglobin solution. During the period of hemoglobinuria, there is little change in $\mathrm{C}_{\mathrm{In}}, \mathrm{C}_{\mathbf{P A H}}$ or filtration fraction (representative experiment).

ure 1). This linearity strongly suggests that the observed hemoglobinuria represents the excretion of a substance whose reabsorptive threshold is exceeded rather than the result of some "toxic" effect of the hemoglobin on the glomerular membrane (15).

As Lambert and Grégoire (16) have demonstrated, the linearity of this relationship is affected by changes in glomerular hemodynamics. In our studies, marked changes occurred in glomerular hemodynamics (see below) but, as can be seen in Figure 2, these changes occurred for the most part before the onset of hemoglobinuria, and re-

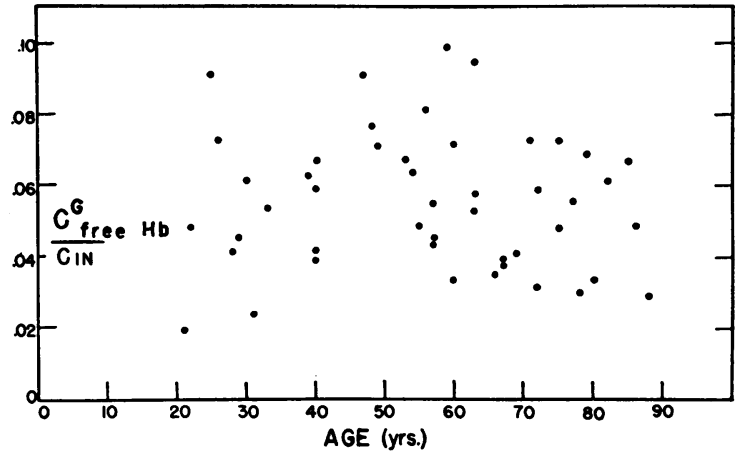

Fig. 3. The Relationship BetWeEN glomerular CLEARANCE OF HEMOGLOBIN RELATIVE TO INULIN $\left(\mathrm{CG}_{\text {free HB}} / \mathrm{C}_{\text {In }}\right)$ AND AGE. EACH POINT REPRESENTS ONE EXPERIMENT.

nal plasma flow and glomerular filtration rate were relatively stable thereafter.

The results of these studies are shown in Figure 3 and Table II. There was no significant correlation between age and glomerular clearance of hemoglobin relative to inulin $(\mathrm{R}=-0.057, \mathrm{p}>$ $0.5)$. The mean for the entire group was $\mathrm{C}^{\mathrm{G}}$ free $\mathrm{Hb} / \mathrm{C}_{\mathrm{In}}=0.055 \pm 0.019(\mathrm{SD})$ which is in close agreement with the value of $0.051 \pm 0.01$ reported by Lathem (4) for a group of 10 healthy men ranging in age from 18 to 48 years.

Considerable variability was noted in the results obtained for four patients studied on two occasions (Table III). This variability of duplicate measurements was also noted by McDonald, Miller and Roach (17).

Renal tubular reabsorption of free hemoglobin. The tubular reabsorption of free hemoglobin was calculated as the difference between filtered load and urinary excretion (Equations 2 and 3 ) for

TABLE II

Correlation of the clearance ratio of free hemoglobin to inulin and $T_{H b}$ with age

\begin{tabular}{|c|c|c|c|c|c|c|c|c|}
\hline \multirow[b]{2}{*}{ Age } & \multirow[b]{2}{*}{$\mathrm{n}$} & \multirow[b]{2}{*}{$\mathrm{C}_{\mathrm{In}} *$} & \multicolumn{3}{|c|}{$\mathrm{CG}_{\text {iree }} \mathrm{Hb} / \mathrm{C}_{\mathrm{In}}$} & \multicolumn{3}{|c|}{$\mathrm{T}_{\mathrm{Hb}}$} \\
\hline & & & $\mathbf{n}$ & Mean & Range & $\mathrm{n}$ & Mean & Range \\
\hline$y r s$ & & $m l / m i n$ & & & & & $m g /$ & \\
\hline \multirow[t]{2}{*}{$\begin{array}{l}20-29 \\
30-39 \\
40-49 \\
50-59 \\
60-69 \\
70-79 \\
80-89\end{array}$} & $\begin{array}{l}6 \\
4 \\
7 \\
8 \\
9 \\
8 \\
5\end{array}$ & $\begin{array}{l}86 \\
81 \\
86 \\
74 \\
66 \\
50 \\
40\end{array}$ & $\begin{array}{l}6 \\
4 \\
7 \\
8 \\
9 \\
8 \\
5\end{array}$ & $\begin{array}{l}0.053 \\
0.050 \\
0.064 \\
0.063 \\
0.051 \\
0.055 \\
0.058\end{array}$ & $\begin{array}{l}0.019-0.092 \\
0.023-0.062 \\
0.039-0.091 \\
0.044-0.099 \\
0.034-0.095 \\
0.030-0.072 \\
0.029-0.067\end{array}$ & $\begin{array}{l}5 \\
3 \\
6 \\
6 \\
6 \\
5 \\
3\end{array}$ & $\begin{array}{l}1.35 \\
1.07 \\
1.97 \\
1.74 \\
1.26 \\
1.12 \\
1.05\end{array}$ & $\begin{array}{l}0.3-4.9 \\
0.5-3.6 \\
0.1-6.4 \\
1.2-8.9 \\
0.9-5.4 \\
0.9-6.1 \\
0.9-6.5\end{array}$ \\
\hline & & \multicolumn{2}{|c|}{ Mean } & 0.055 & & & 1.43 & \\
\hline
\end{tabular}

* Mean inulin clearance during the periods of hemoglobinuria. 
TABLE III

Values for $\mathrm{C}_{\text {free } \mathrm{Hb}} / \mathrm{C}_{\mathrm{In}}$ and $\mathrm{T}_{\mathrm{Hb}}$ obtained on repeat tests

\begin{tabular}{crcc}
\hline \hline Subject & Date & $\mathrm{CG}_{\text {free Hb} / \mathrm{C}_{\text {In }}}$ & $\mathrm{T}_{\text {Hb }}$ \\
\hline \multirow{2}{*}{ Ade } & $11 / 24 / 59$ & 0.099 & $m g / \min$ \\
& $2 / 9 / 60$ & 0.055 & 3.18 \\
Lee & $7 / 21 / 59$ & 0.034 & 1.33 \\
& $3 / 22 / 60$ & 0.048 & 2.15 \\
Reu & $3 / 10 / 59$ & 0.035 & 2.47 \\
Sie & $2 / 9 / 60$ & 0.059 & 0.80 \\
& $3 / 17 / 59$ & 0.058 & 1.98 \\
& $3 / 14 / 60$ & 0.077 & 2.04 \\
\hline
\end{tabular}

the 34 experiments in which the ratio exceeded 3 (load $\mathrm{T}_{\mathbf{H b}}$; Table II). There was no significant correlation with age $(R=0.092, p>0.5)$. The mean value for the entire group, $\mathrm{T}_{\text {free } \mathbf{~} \mathbf{b}}=1.43$ $\pm 0.96 \mathrm{mg}$ per minute, may be compared with that reported by Lathem (4) $(1.30 \pm 0.9 \mathrm{mg}$ per minute).

Hemodynamic changes. The intravenous administration of a solution of autogenous hemoglobin, containing also those erythrocyte components that did not sediment with the erythrocyte stroma, consistently resulted in the following changes : 1) decrease in $\mathrm{C}_{\mathrm{In}} ; 2$ ) decrease in $\mathrm{C}_{\mathrm{PAH}}$; and 3) increase in filtration fraction (Figure 2). Although the renal extraction of para-aminohippurate was not measured, the studies of Miller and McDonald (18) and Brandt, Frank and Lichtman (19) suggest that the fall in $\mathrm{C}_{\mathbf{P A H}}$ after administration of hemoglobin represents a true decrease in renal plasma flow. Table IV shows the changes observed in $\mathrm{C}_{\mathrm{In}}, \mathrm{C}_{\mathrm{PAH}}$ and filtration fraction $(\mathrm{FF})$.
It may be seen that the maximal decrease in $\mathrm{C}_{\text {In }}$ and $\mathrm{C}_{\mathrm{PAH}}$ averaged 36 and 56 per cent, respectively. The maximal increase in filtration fraction averaged 50 per cent. Only the latter showed a significant correlation with age $(R=-0.407$, $\mathrm{p}<0.005$ ).

\section{DISCUSSION}

Knowledge of the mechanism of transglomerular transport of both large and small molecules is at present incomplete. Chinard (20) has proposed that substances pass across the glomerular membrane by a process of diffusion through a gel or fine lattice structure. The "pore theory" as propounded by Pappenheimer, Renkin and Borrero $(21,22)$ envisions transport of lipid-insoluble substances through pores whose total area constitutes only a small fraction of the surface area of the glomerular membrane. It has been demonstrated that the rate of transglomerular transport of various substances is influenced by changes in the glomerular membrane $(23,24)$ and under conditions which would be expected to produce pressure changes within the glomerulus $(16,25$, 26).

In the present study we have not been able to demonstrate a significant age trend in glomerular clearance of hemoglobin relative to inulin (sieving ratio). We have examined our data to determine whether there was any systematic difference in the hemodynamic response to hemoglobin infusion which might mask a systematic change in membrane permeability. Such a factor might be ex-

TABLE IV

Correlation of hemodynamic changes with age and glomerular clearance of hemoglobin induced by infusion of hemoglobin

\begin{tabular}{|c|c|c|c|c|c|c|c|c|c|c|}
\hline \multirow[b]{2}{*}{ Age } & \multirow[b]{2}{*}{$\mathrm{n}$} & \multicolumn{3}{|c|}{$\mathrm{C}_{\mathrm{In}}$} & \multicolumn{3}{|c|}{$\mathrm{C}_{\mathrm{PAH}}$} & \multicolumn{3}{|c|}{ Filtration fraction } \\
\hline & & Control* & Maximum $†$ & Change & Control* & Maximum $\dagger$ & Change & Control* & Maximum $†$ & Change \\
\hline$y r s$ & & $m l / m i n$ & $\mathrm{ml} / \mathrm{min}$ & $\%$ & $\mathrm{ml} / \mathrm{min}$ & $\mathrm{ml} / \min$ & $\%$ & & & $\%$ \\
\hline $\begin{array}{l}20-29 \\
30-39 \\
40-49 \\
50-59 \\
60-69 \\
70-79 \\
80-89\end{array}$ & $\begin{array}{l}6 \\
4 \\
7 \\
8 \\
9 \\
9 \\
8 \\
5\end{array}$ & $\begin{array}{r}125 \\
119 \\
106 \\
104 \\
87 \\
84 \\
59\end{array}$ & $\begin{array}{l}76 \\
75 \\
69 \\
69 \\
61 \\
43 \\
33\end{array}$ & $\begin{array}{l}-39 \\
-37 \\
-34 \\
-34 \\
-30 \\
-49 \\
-44\end{array}$ & $\begin{array}{l}641 \\
610 \\
541 \\
464 \\
366 \\
364 \\
219\end{array}$ & $\begin{array}{l}250 \\
261 \\
214 \\
214 \\
179 \\
135 \\
104\end{array}$ & $\begin{array}{l}-61 \\
-57 \\
-60 \\
-54 \\
-51 \\
-63 \\
-53\end{array}$ & $\begin{array}{l}0.20 \\
0.21 \\
0.20 \\
0.23 \\
0.25 \\
0.24 \\
0.27\end{array}$ & $\begin{array}{l}0.32 \\
0.32 \\
0.34 \\
0.34 \\
0.36 \\
0.33 \\
0.33\end{array}$ & $\begin{array}{l}61 \\
54 \\
69 \\
51 \\
46 \\
39 \\
20\end{array}$ \\
\hline Mean & & & & $-37 \pm 12$ & & & $-56 \pm 10$ & & & $50 \pm 27$ \\
\hline \multicolumn{4}{|c|}{$\begin{array}{l}\text { Correlation with age } \\
\text { Correlation with } \mathrm{CG}_{\text {free } \mathrm{Hb}} / \mathrm{C}_{\mathrm{In}}\end{array}$} & NS & & & $\begin{array}{l}\text { NS } \\
\text { NS }\end{array}$ & & & $\begin{array}{l}-0.41 \ddagger \\
\text { NS }\end{array}$ \\
\hline
\end{tabular}

* Clearance prior to hemoglobin infusion.

† Mean of two consecutive periods with maximal displacement from control.

$\ddagger \mathrm{p}<0.005$. 
pected to correlate significantly with age and with $\mathrm{C}_{\text {free }}$ нb/ $\mathrm{C}_{\text {In }}$. Table IV shows that none of the hemodynamic parameters examined, i.e., $\Delta \mathrm{C}_{\mathrm{In}}$, $\Delta \mathrm{C}_{\mathrm{PAB}}$ or $\Delta \mathrm{FF}$, shows a significant correlation with both age and $\mathrm{C}_{\mathrm{Hb}} / \mathrm{C}_{\mathrm{In}}$. While our results indicate no systematic age difference in glomerular permeability to hemoglobin, the limitations of the method used here for determination of glomerular permeability, with regard to reliability and the influence of changes in glomerular hemodynamics, do not permit us to rule out with certainty some changes in glomerular permeability to hemoglobin with age.

In the present studies, renal tubular reabsorption of unbound hemoglobin averaged $1.43 \pm 0.96$ $\mathrm{mg}$ per minute with a range of 0.06 to 4.41 . The estimation of tubular reabsorption of hemoglobin is based on the arithmetic difference between two variables-filtered load and urinary excretionboth of which are considerably greater in magnitude than their difference. Because of the errors inherent in the measurement of these two variables, estimation of the magnitude of tubular reabsorption shows considerable variability. It should be noted that in every subject examined in our study, there was some physiologic evidence of reabsorption of hemoglobin. Morphologic evidence presented by Rather (27) and summarized by Smith (15) supports the concept that tubular reabsorption of hemoglobin occurs to some degree. Recentiy, Lathem, Davis, Zweig and Dew (28) have found evidence of proximal tubular reabsorption of hemoglobin during stop flow experiments in the dog. The fact that tubular reabsorption of hemoglobin in the dog can be demonstrated by stop flow analysis but not by standard clearance procedures (3) suggests that perhaps the reabsorptive process approaches equilibrium very slowly. This factor of time of contact between tubular contents and renal epithelium has not been evaluated in the present work.

\section{SUMMARY}

1. The glomerular clearance of free hemoglobin relative to inulin $\left(\mathrm{C}_{\text {free } \mathrm{Hb}} / \mathrm{C}_{\mathrm{In}}\right.$ ) was measured in 47 adult males free of demonstrable renal disease. The average value of $\mathrm{C}^{\mathrm{G}_{\text {free }}} \mathrm{Hb} / \mathrm{C}_{\text {In }}$ was $0.055 \pm 0.019$. No significant correlation between $\mathrm{C}_{\text {free } \mathbf{H b}} / \mathrm{C}_{\text {In }}$ and age was found.
2. The estimation of renal tubular reabsorption of free hemoglobin in 34 patients, in whom the ratio of filtered load to reabsorption exceeded 3 , averaged $1.43 \pm 0.96 \mathrm{mg}$ per minute with a range of 0.06 to 4.41 .

3. On the basis of these studies we have not been able to demonstrate a significant correlation between age and glomerular permeability to hemoglobin. Because of the limitations of the method for the determination of glomerular permeability, we cannot say with assurance that some systematic change in glomerular permeability with age does not exist.

4. Additional evidence for renal tubular reabsorption of hemoglobin is provided by the presence of a measurable $\mathrm{T}_{\mathrm{Hb}}$ in every case studied.

\section{ACKNOWLEDGMENT}

The authors gratefully acknowledge the technical assistance of Miss Margaret Sellmayer, Mrs. Ramona Dorcas and Mrs. Theresa Caryk in performing the analyses and Mrs. Fowler and nursing staff of B-2 for their invaluable assistance.

\section{REFERENCES}

1. Polonovski, M., and Jayle, M. Existence dans le plasma sanguin d'une substance activant l'action peroxydasique de l'hémoglobine. C. R. Soc. Biol. (Paris) 1938, 129, 457.

2. Jayle, M. F., Boussier, G., and Badin, J. Electrophorèse de l'haptoglobine et de son complexe hémoglobinique. Bull. Soc. Chim. biol. (Paris) 1952, 34, 1063.

3. Vanderveiken, F., Gueritte, F., de Myttenaere, M., and Lambert, P. P. Effets de la liaison hémoglobine-haptoglobine sur l'excrétion de l'hémoglobine. J. Urol. méd. chir. 1958, 64, 136.

4. Lathem, W. The renal excretion of hemoglobin: Regulatory mechanisms and the differential excretion of free and protein-bound hemoglobin. J. clin. Invest. 1959, 38, 652.

5. Miller, J. H., McDonald, R. K., and Shock, N. W. Age changes in the maximal rate of renal tubular reabsorption of glucose. J. Geront. 1952, 7, 196.

6. Davies, D. F., and Shock, N. W. Age changes in glomerular filtration rate, effective renal plasma flow, and tubular excretory capacity in adult males. J. clin. Invest. 1950, 29, 496.

7. Everitt, A. V. The urinary excretion of protein, nonprotein nitrogen, creatinine and uric acid in ageing male rats. Gerontologia (Basel) 1958, 2, 33.

8. Thung, P. J. Proteinuria in mice and its relevance to comparative gerontology. Experientia (Basel) 1956, suppl. IV, 195. 
9. Smith, H. W., Goldring, W., and Chasis, H. The measurement of the tubular excretory mass, effective blood flow and filtration rate in the normal human kidney. J. clin. Invest. 1938, 17, 263.

10. Lathem, W., and Worley, W. E. The distribution of extracorpuscular hemoglobin in circulating plasma. J. clin. Invest. 1959, 38, 474.

11. Harrison, H. E. A modification of the diphenylamine method for determination of inulin. Proc. Soc. exp. Biol. (N. Y.) 1942, 49, 111.

12. Bratton, A. C., and Marshall, E. K., Jr. A new coupling component for sulfanilamide determination. J. biol. Chem. 1939, 128, 537.

13. McCall, K. B. Spectrophotometric determination of total hemoglobin in plasma. Analyt. Chem. 1956, 28, 189.

14. Crosby, W. H., and Furth, F. W. A modification of the benzidine method for measurement of hemoglobin in plasma and urine. Blood 1956, 11, 380.

15. Smith, H. W. The Kidney: Structure and Function in Health and Disease. New York, Oxford Univ. Press, 1951, p. 1049.

16. Lambert, P. P., and Grégoire, F. Hémodynamique glomérulaire et excrétion de l'hémoglobine. Arch. int. Physiol. 1955, 63, 7.

17. McDonald, R. K., Miller, J. H., and Roach, E. B. Human glomerular permeability and tubular recovery values for hemoglobin. J. clin. Invest. 1951, 30, 1041.

18. Miller, J. H., and McDonald, R. K. The effect of hemoglobin on renal function in the human. J. clin. Invest. 1951, 30, 1033.

19. Brandt, J. L., Frank, N. R., and Lichtman, H. C. Effects of hemoglobin solutions on renal functions in man. Blood 1951, 6, 1152.

20. Chinard, F. P. Derivation of an expression for the rate of formation of glomerular fluid (GFR).
Applicability of certain physical and physico-chemical concepts. Amer. J. Physiol. 1952, 171, 578.

21. Pappenheimer, J. R. Uber die Permeabilität der Glomerulummembranen in der Niere. Klin. Wschr. $1955,33,362$.

22. Pappenheimer, J. R., Renkin, E. M., and Borrero, L. M. Filtration, diffusion, and molecular sieving through peripheral capillary membranes. A contribution to the pore theory of capillary permeability. Amer. J. Physiol. 1951, 167, 13.

23. Malmendier, C., Grégoire, F., and Lambert, P. P. Résultats des épreuves de surcharge en albumine pratiquées chez des patients atteints de glomérulonéphrite chronique. J. Urol. méd. chir. 1958, 64, 143.

24. Wallenius, G. Renal clearance of dextran as a measure of glomerular permeability. Acta Soc. Med. upsalien. 1954, suppl. 4, 59.

25. Chinard, F. P., Lauson, H. D., Eder, H. A., Greif, R. L., and Hiller, A. A study of the mechanism of proteinuria in patients with the nephrotic syndrome. J. clin. Invest. 1954, 33, 621.

26. Lathem, W., and Benjamin, A. D. Urinary hemoglobin excretion and renal circulatory dynamics: A study of the effect of L-norepinephrine in the dog. J. clin. Invest. 1957, 36, 89.

27. Rather, L. J. Renal athrocytosis and intracellular digestion of intraperitoneally injected hemoglobin in rats. J. exp. Med. 1948, 87, 163.

28. Lathem, W., Davis, B. B., Zweig, P. H., and Dew, $R$. The demonstration and localization of renal tubular reabsorption of hemoglobin by stop flow analysis. J. clin. Invest. 1960, 39, 840.

29. Snedecor, G. W. Statistical Methods Applied to Experiments in Agriculture and Biology, 5th ed. Ames, Iowa State College Press, 1956, p. 534. 